Volume 1, Nomor 1, Juni 2017

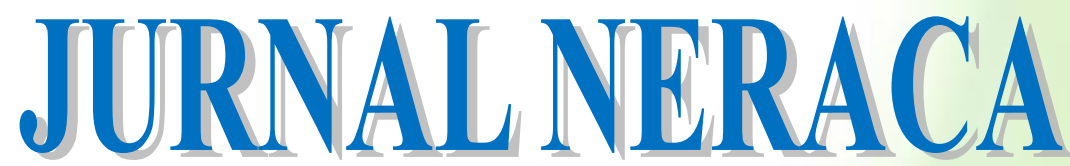

Jurnal Pendidikan dan Ilmu Ekonomi Akuntansi

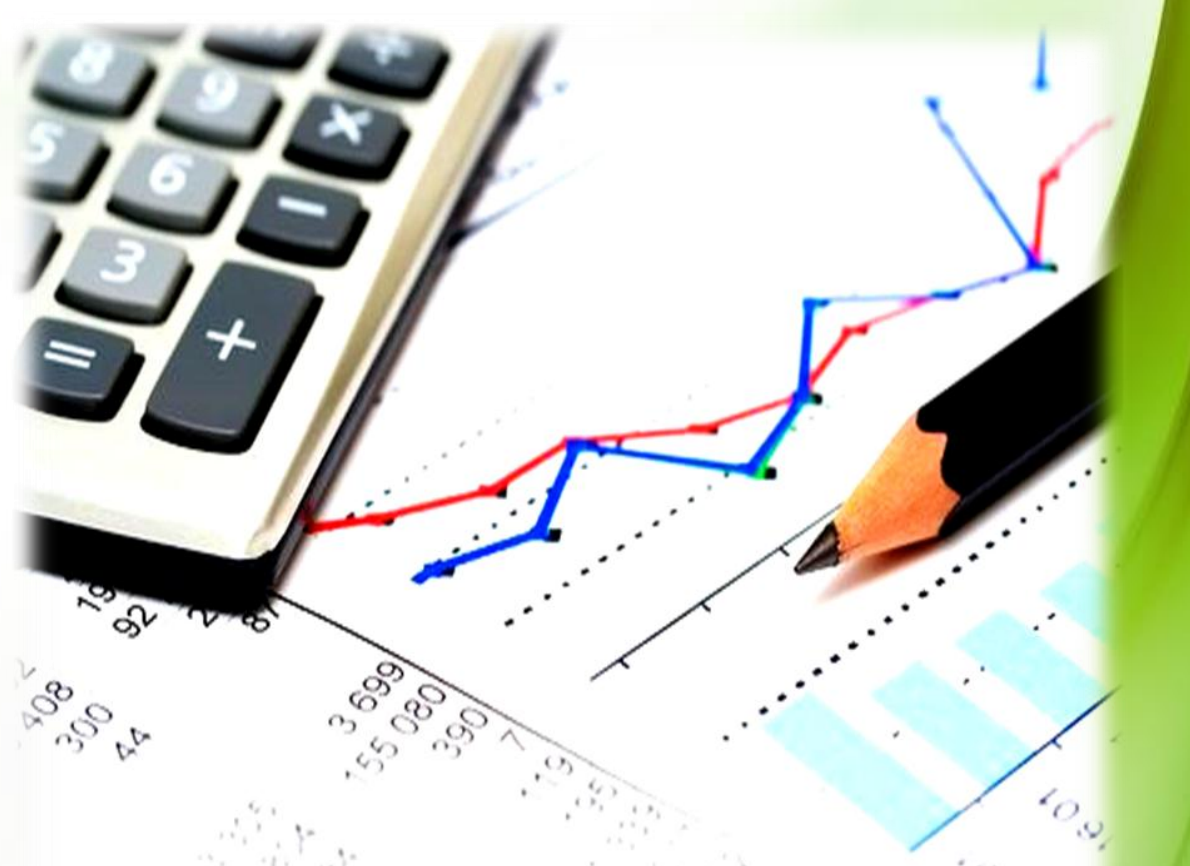

Diterbitkan oleh:

Program Studi Pendidikan Akuntansi

Fakultas Keguruan dan Ilmu Pendidikan Universitas PGRI Palembang

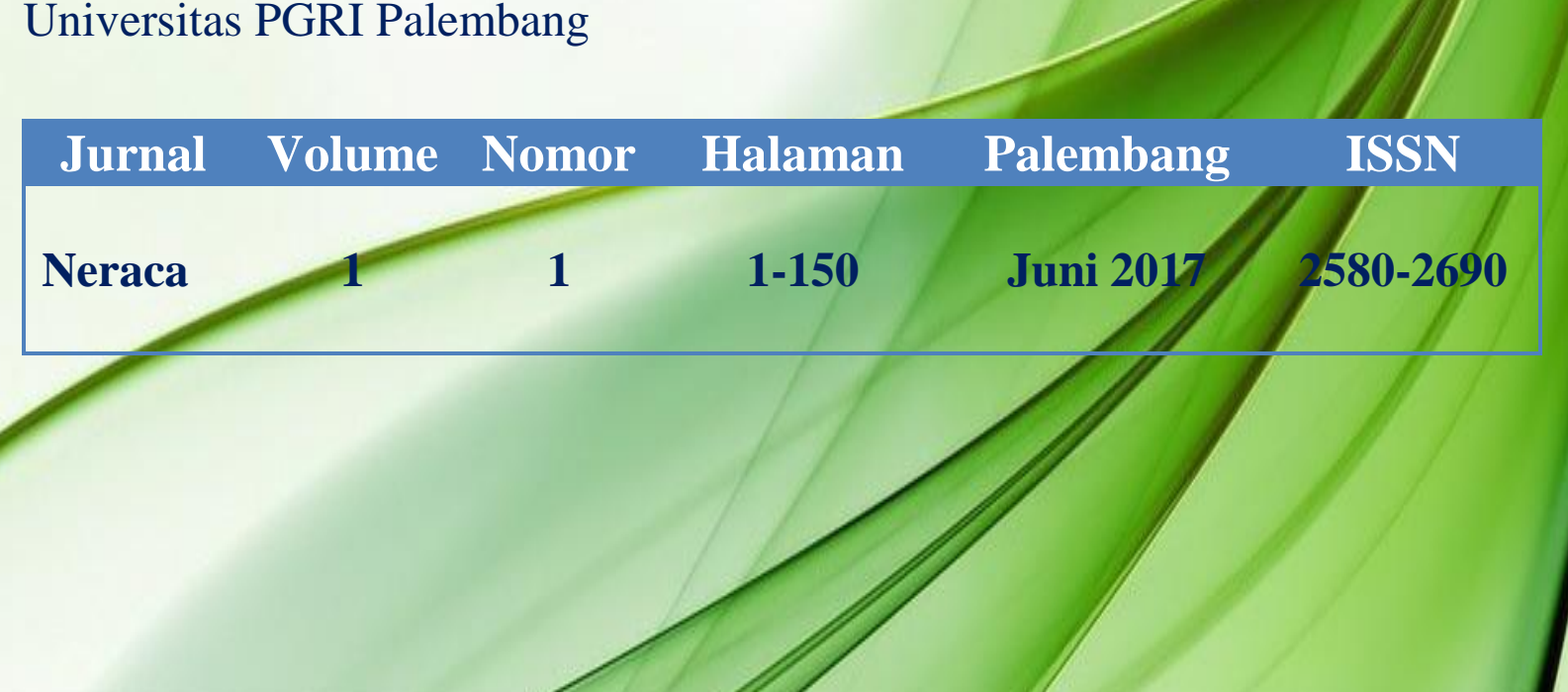




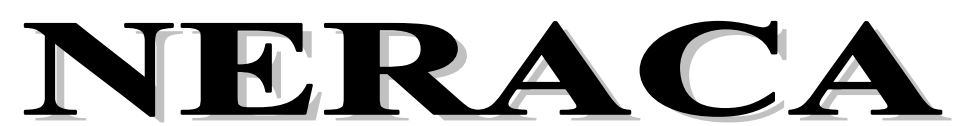

Jurnal Pendidikan dan Ilmu Ekonomi Akuntansi

Volume 1, Nomor 1, Juni 2017

\title{
DEWAN PENYUNTING
}

Penanggung Jawab

Dra. Andinasari, M.M., M.Pd

Drs. Sukardi, M.Pd

Ketua Dewan Penyunting

Zahruddin Hodsay, S.Pd., M.Si

\section{Wakil Ketua Dewan Penyunting}

Erma Yulaini, S,Pd., M.Si

\section{Sekretaris}

Depi Pramika, S.Pd., M.Si

\author{
Penyunting Pelaksana \\ Januardi, S.Pd., M.Si \\ M. Toyib, M.Pd
}

Diana Widhi Rachmawati, S.IP., M.M

Nuryanti Permatasari, S.E.Ak., M.M

\section{Penyunting Ahli}

Prof. Dr. H.M. Djahir Basir, M.Pd (Universitas Sriwijaya)

Dr. H. Syarwani Ahmad, M.M (Universitas PGRI Palembang)

Dr. Maya Panorama, M.Si (Universitas Islam Negeri Raden Fatah Palembang)

Dr. Riswan Jaenudin, M.Pd (Universitas Sriwijaya)

Dr. Hamidah, M.Si (Universitas Negeri Jakarta)

Dr. H. Nugraha, M.Si.Ak.CA (Universitas Pendidikan Indonesia Bandung)

\author{
Setting \\ Hendri Gunawan, S.Pd., M.Pd \\ Merlyn Widalismana, M.Pd \\ Chandra Kurniawan, SE., M.Si \\ Bendahara \\ Neta Dian Lestari, S.Pd., M.M \\ Sekretariatan \\ Juniarti, SE
}

\section{Alamat Penyunting}

Program Studi Pendidikan Akuntansi

Fakultas Keguruan dan Ilmu Pendidikan Universitas PGRI Palembang Telp. 0711-510043, Fax. 0711-514782. Email: prodipend.akuntansi@ gmail.com Website: www.univpgri-palembang.ac.id

Jurnal NERACA , jurnal pendidikan dan ilmu ekonomi akuntansi diterbitkan oleh Program Studi Pendidikan Akuntansi, FKIP Universitas PGRI Palembang

Frekuesi terbit: Dua kali setahun, setiap bulan Juni dan Desember

Penyunting menerima sumbangan tulisan yang belum pernah diterbitkan pada media lain.

Naskah yang masuk dievaluasi oleh Penyunting Pelaksana dan Penyunting Ahli. Penyunting dapat melakukan perubahan pada tulisan yang dimuat untuk keseragaman format, tanpa mengubah maksud dan isinya 


\section{PENGANTAR PENYUNTING}

Jurnal Neraca diterbitkan dalam rangka untuk memenuhi kebutuhan pengetahuan dan informasi dalam bidang pendidikan dan ilmu ekonomi, serta pendidikan dan ilmu akuntansi. Edisi pertama Jurnal Neraca (Volume 1, Nomor 1) ini menurunkan sepuluh artikel yang terdiri dari artikel pendidikan ekonomi akuntansi, dan ilmu ekonomi akuntansi . Dengan kata lain, edisi pertama jurnal ini tidak membatasi diri pada isu tertentu ataupun membatasi diri pada artikel-artikel yang berbasis hasil riset eksperimental. Meski demikian pilihan tersebut tidak mengurangi bobot ilmiah dari edisi pertama ini. Dari sisi metodologi, tulisantulisan yang diturunkan dalam edisi ini sebagian berbasis penelitian eksperimen, sebagian menggunakan penelitian survei dan sebagian lagi berbasis pada studi literatur.

Artikel pertama menampilkan hasil penelitian dari Delvina Yulanda tentang pengaruh kompetensi dan disiplin terhadap kepuasan kerja serta implikasinya pada prestasi kerja karyawan PT. Smartfren Telecom Palembang. Analisis data dilakukan dengan Structural Equation Model (SEM) menggunakan perangkat lunak Amos. Penelitian tersebut menunjukan bahwa ada pengaruh positif secara parsial dan simultan dari variabel kompetensi dan disiplin kerja terhadap kepuasan kerja serta implikasinya pada prestasi kerja karyawan PT. Smartfren Telecom Palembang. Artikel kedua dari Depi Pramika dan Nurmala Sari tentang adanya pengaruh komunikasi dan gaji terhadap kinerja karyawan PT. Finansia Multi Finance Palembang. Metode penelitian yang digunakan adalah penelitian deskriptif asosiatif. Artikel ketiga dari Diana Widhi Racmawati tentang Kinerja Keuangan Koperasi sekolah di SMK Negeri 3 Palembang yang menunjukkan tidak solvabel, karena pihak koperasi sekolah di SMK Negeri 3 Palembang belum melakukan pinjaman atau hutang pada pihak luar.

Artikel keempat kajian literatur mengenai analisis kebijakan pendidikan terhadap tenaga kependidikan dalam menghadapi Masyarakat Ekonomi Asean (MEA) yang ditulis oleh Erma Yulaini. Artikel kelima oleh Febriansyah mengenai adanya pengaruh penerapan metode Kombinasi Ceramah, Demonstrasi dan Latihan (CDL) terhadap hasil belajar komputer akuntansi siswa kelas XI (baik kelas kontrol maupun eksperimen) di SMK Negeri 1 Palembang Tahun Ajaran 2015/2016. Artikel keenam ditulis oleh Irma Yuningsih, Andrieta Shintia Dewi, dan Tieka Trikartika Gustyana mengenai analisis literasi keuangan di masyarakat kota Bandung, dengan menghasilkan variable financial behavior berpengaruh terhadap literasi keuangan kota Bandung. Artikel ketujuh penelitian dari Neta Dian Lestari mengenai adanya perbedaan hasil belajar akuntansi siswa dalam penerapan konsep psikologi kapital intelektual dengan kapital sosial, dan hasil belajar dengan konsep psikologi intelektual lebih tinggi dibandingkan dengan kapital sosial di SMK Muhammadiyah 2 Palembang tahun pelajaran 2014/2015.

Artikel kedelapan dari Rosananda Oktala tentang pengaruh GCG terhadap kinerja perusahaan LQ45 yang terdaftar di Bursa Efek Indonesia, namun hasil penelitiannya menunjukkan GCG tidak mempengaruhi kinerja perusahaan LQ 45. Kesembilan artikel dari Suyanto dan Ati Nursanti dengan judul faktor-faktor yang memengaruhi harga saham perusahaan food and beverage yang terdaftar di bursa efek Indonesa. Artikel terakhir yaitu dari Zahruddin Hodsay dan Yana Yupiko mengenai Pengaruh Motivasi Belajar Siswa Terhadap Perilaku Belajar Siswa dan pengaruh (dampak) perilaku belajar terhadap Prestasi Belajar Siswa Pada Mata Pelajaran Ekonomi Di SMA Negeri 12 Palembang Tahun Pelajaran 2015/201 6. Hasilnya menunjukkan adanya pengaruh yang signifikan motivasi belajar terhadap prilaku belajar dan adanya efek langsung perilaku belajar terhadap prestasi belajar.

Akhir kata, kami mengucapkan terima kasih kepada berbagai pihak karena edisi dalam jurnal Nerca ini dapat terlaksana atas bantuan dari berbagai pihak, terkhusus kerja para penyunting, tata letak dan penyumbang artikel dari para penulis. Semoga pada edisi berikutnya akan lebih mampu menyajikan tematema riset yang lebih bervariasi sehingga mampu memperluas pengetahuan di bidang pendidikan dan ilmu akuntansi ekonomi kita semua. 


\section{JURNAL NERACA}

Jurnal Pendidikan dan Ilmu Ekonomi Akuntansi

Volume 1, Nomor 1, Juni 2017

DAFTAR ISI

Pengaruh Kompetensi dan Disiplin terhadap Kepuasan Kerja serta Implikasinya pada Prestasi Kerja Karyawan PT. Smartfren Telecom Palembang, 1-15

Delvina Yulanda

Pengaruh Komunikasi dan Gaji Terhadap Kinerja Karyawan pada PT. Finansia Multi Finance

Palembang, 16-26

Depi Pramika

Nurmala Sari

Kinerja Keuangan Koperasi Pelajar SMK Negeri 3 Palembang Dilihat dari Rasio Solvabilitas, 27-35

Diana Widhi Rachmawati

Analisis Kebijakan Pendidikan Terhadap Tenaga Kependidikan dalam Menghadapi Masyarakat

Ekonomi Asean (MEA), 36-48

Erma Yulaini

Pengaruh Penerapan Metode Kombinasi Ceramah, Demonstrasi dan Latihan (CDL) Terhadap Hasil Belajar Komputer Akuntansi Siswa di SMK Negeri 1 Palembang Tahun Ajaran 2015/2016,49-62

Febriansyah

Analisis Literasi Keuangan di Masyarakat Kota Bandung, 63-74

Irma Yuningsi

Andrieta Shintia Dewi

Tieka Trikartika Gustyana

Perbedaan Hasil Belajar Akuntansi Siswa dalam Penerapan Konsep Psikologi Kapital Intelektual dengan Kapital Sosial di SMK Muhammadiyah 2 Palembang Tahun Pelajaran 2014/2015, 75-98

Neta Dian Lestari

Pengaruh Penerapan Good Corporate Governance (GCG) Terhadap Kinerja Perusahaan (Studi Kasus Perusahaan LQ 45), 99-108

Rosananda Oktala

Faktor-Faktor yang Memengaruhi Harga Saham Perusahaan Food and Beverage yang Terdaftar di Bursa Efek Indonesa, 109-126

Suyanto

Ati Nursanti

Analisis Rasio Laporan Keuangan Koperasi Pelajar di SMK Negeri 1 Palembang, 127-150 Zahruddin Hodsay

Fitria Nurjanah 


\title{
FAKTOR-FAKTOR YANG MEMENGARUHI HARGA SAHAM PERUSAHAAN FOOD AND BEVERAGE YANG TERDAFTAR DI BURSA EFEK INDONESA
}

\author{
Oleh: Suyanto ${ }^{1}$ dan Ati Nursanti ${ }^{2}$ \\ (Sekolah Tinggi Ilmu Ekonomi IPWI Jakarta) \\ $\underline{\text { suyantowalidi@gmail.com }}^{1}$, aty_nursanti@yahoo.com ${ }^{2}$
}

\begin{abstract}
Before performing stock investment, individual or company must ensure that the investment is appropriate. This can be done by applying a variety of alternative ways of assessing whether the selected stock is really a stock that will provide benefits in the future. One alternative is a fundamental analysis of investment appraisal or performance of the company. Return On Asset, Debt to Total Asset and Net Profit Margin is a ratio that shows the company's ability to generate profit and the ratio that measures total corporate debt financed by the assets of the company, which is one way to find out the performance of the company. This research is purposed to determine the influence of Return On Asset, Debt to Total Asset and Net Profit Margin towards Stock Prices. The population in this reaserch are Go Public companies, Food and Beverage Sector, which listed in Indonesian Stock Exchange during 2010-2015 period. Sample selection technique in this research is purposive sampling. Nine companie have been acquired that meet the research sample criteria. This research use secondary data who analyzed with descriptive method and multiple linier regression who tested with experiment classic assumption. The result of research point out indeed Return On Asset, Debt to Total Asset, and Net Profit Margin according to simultaneous influential significant toward dependence variabel is stock prices. According to partial Return On Asset and Debt to Total Asset in not influential significant toward stock prices to Food and Beverage business who listed in Indonesian Stock Exchange period 2010-2015. Meanwhile Net Profit Margin have influence significant toward stock prices to Food and Beverage business who listed in Indonesian Stock Exchange period 2010-2015.
\end{abstract}

\section{Keyword : Return On Asset, Debt to Total Asset, Net Profit Margin, Stock Prices}

\section{PENDAHULUAN}

Sektor yang dianggap bisa bertahan dalam terjangan krisis global adalah sektor konsumsi terutama industri makanan dan minuman. Hal itu dikatakan Kepala Lembaga Penyelidikan Ekonomi dan Masyarakat Fakultas Ekonomi Universitas Indonesia (LPEM-FEUI) dalam Media Training, Prospek Ekonomi dan Tantangan Industri Manufacture 2009, di Hotel
Sheraton, Yogyakarta. Alasannya sejak krisis ekonomi yang terjadi pada pertengahan 2008, hanya industri Makanan dan Minuman yang dapat bertahan.

Indusrtri Food and Baverage adalah yang paling baik dan bertahan pada krisis global. Industri makanan dan minuman dapat bertahan tidak bergantung pada bahan baku impor dan lebih banyak mengggunakan bahan baku domestik. 
Selain itu, karakteristik masyarakat cenderung gemar berbelanja makanan, ikut membantu mempertahankan industri makanan dan minuman.

Tujuan perusahaan menerbitkan saham adalah untuk memeroleh modal usaha yang akan digunakan untuk kegiatan operasi perusahaan. Perusahaan selalu berusaha untuk memaksimalkan nilai sahamnya agar banyak investor yang tertarik menanamkan modalnya untuk perusahaan. Sebelum berinvestasi, calon investor akan melihat kinerja keuangan perusahaan yang selanjutnya akan digunakan sebagai acuan untuk memilih perusahaan mana yang akan dipilih untuk berinvesatsi.

Selain melihat kinerja perusahaan, investor sangat memeperhatikan harga saham perusahaan yang akan dibelinya. Hal ini dikarenakan investor mengharapkan keuntungan dari investasi tersebut. Harga saham merupakan cerminan dari ekspektasi investor terhadap faktor-faktor earning,aliran kas, dan tingkat return yang disyaratkan investor, yang mana ketiga faktor tersebut juga sangat dipengaruhi oleh kondisi ekonomi makro suatu negara serta kondisi ekonomi global (Tandelilin,2010:341).

Harga saham di bursa efek akan ditentukan oleh kekuatan permintaan dan penawaran. Pada saat permintaan saham meningkat, maka harga saham tersebut akan cenderung meningkatkan. Sebaliknya, pada saat banyak orang menjual saham, maka harga saham tersebut cenderung akan mengalami penurunan (Pakarti dan Anoraga, 2001: 60).

Variasi harga saham ditentukan oleh banyak faktor baik yang berasal dari lingkungan eksternal maupun internal perusahaan.Menurut Alwi (2008:87), faktor-faktor yang mempengaruhi pergerakan harga saham yaitu:

\section{A. Faktor Internal}

1. Pengumuman tentang pemasaran, produksi, penjualan seperti pengiklanan, rincian kontrak, perubahan harga, penarikan produk baru, laporan produksi, laporan keamanan produk, dan laporan penjualan.

2. Pengumuman pendanaan (financing announcements), seperti pengumuman yang berhubungan dengan ekuitas dan hutang.

3. Pengumuman badan direksi manajemen (management board of director announcements) seperti perubahan dan pergantian direktur, manajemen, dan struktur organisasi.

4. Pengumuman pengambilalihan diversifikasi, seperti laporan merger, investasi ekuitas, laporan 
take over oleh pengakusisian dan diakuisisi.

5. Pengumuman investasi (investment announcements), seperti melakukan ekspansi pabrik, pengembangan riset dan penutupan usaha lainnya.

6. Pengumuman ketenagakerjaan (labour announcements), seperti negoisasi baru, kontrak baru, pemogokan dan lainnya.

7. Pengumuman laporan keuangan perusahaan, seperti peramalan laba sebelum akhir tahun fiskal dan setelah akhir tahun fiskal, Earning Per Share (EPS), Dividen Per Share (DPS), price earning ratio, net profit margin, return on assets (ROA), dan lain-lain.

\section{B. Faktor Eksternal}

1. Pengumuman dari pemerintah seperti perubahan suku bunga tabungan dan deposito, kurs valuta asing, inflasi, serta berbagai regulasi dan deregulasi ekonomi yang dikeluarkan oleh pemerintah.

2. Pengumuman hukum (legal announcements), seperti tuntutan karyawan terhadap perusahaan atau terhadap manajernya dan tuntutan perusahaan terhadap manajernya.

3. Pengumuman industri sekuritas (securities announcements), seperti laporan pertemuan tahunan, insider trading, volume atau harga saham perdagangan,

pembatasan/penundaan trading.

4. Gejolak politik dalam negeri dan fluktuasi nilai tukar juga merupakan faktor yang berpengaruh signifikan pada terjadinya pergerakan harga saham di bursa efek suatu negara.

5. Berbagai isu baik dari dalam dan luar negeri.

Gambar 1.1

Rata-rata Harga Saham Industri Food and Beverage

Tahun 2010-2015

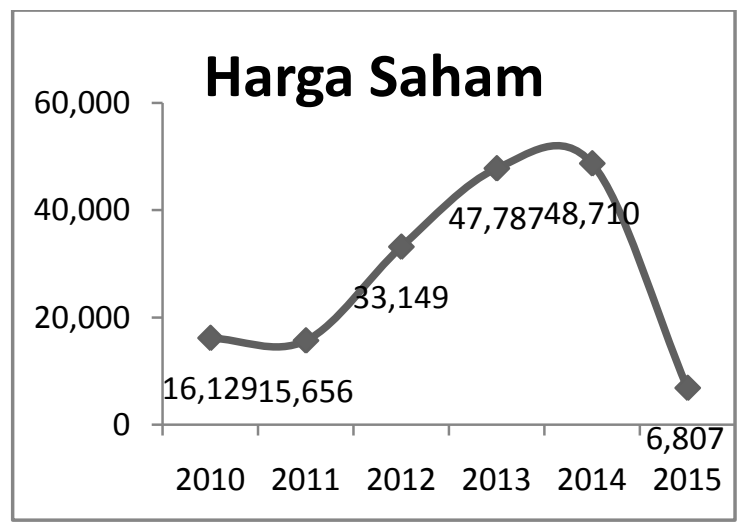

Sumber : Bursa Efek Indonesia diolah

Grafik tersebut merupakan perkembangan harga saham dari indeks subsektor Food and Beverage Periode 2010-2014. Dilihat dari pergerakan grafik tersebut, harga saham mengalami fluktuasi. Tetapi secara umum dapat dikatakan perkembangan saham subsektor 
Food and Beverage dari tahun 2010-2015 mengalami peningkatan harga saham. Melihat dari pergerakan grafik diatas dapat diambil kesimpulan bahwa perusahaan Food and Beverage banyak diminati oleh investor yang berdampak pada meningkatnya harga saham karena banyaknya investor yang tertarik akan saham sektor tersebut. Perkembangan harga saham diatas sangat berfluktuasi sehingga fenomena ini menarik untuk diteliti, sesuai dengan penelitian terdahulu bahwa harga saham ini dipengaruhi oleh beberapa faktor. Salah satunya adalah faktor fundamental.

informasi fundamental adalah informasi yang berhubungan dengan kondisi perusahaan yang umumnya ditunjukan dalam lapoan keuangan yang merupakan salah satu ukuran kinerja perusahaan. Informasi fundamental sering digunakan untuk memprediksi harga saham. Analisis fundamental berkaitan dengan penilaian kinerja perusahaan tentang efektifitas dan efisien perusahaan dalam mencapai sasaran. Dalam penelitian ini peneliti bertujuan untuk menganalisis pengaruh faktor fundamental seperti Return On Asset (ROA), Debt to Total Asset Ratio (DAR), dan Net Profit Margin (NPM) terhadap harga saham perusahaan Food and Baverage periode 2010-2015 baik secara Simultan maupun Parsial. Serta untuk mengetahui variabel apa yang memberikan pengaruh paling dominan.Analisis keuangan pada dasarnya dilakukan untuk mengevaluasi kinerja dimasa lalu dengan melakukan berbagai analisis sehingga diperoleh posisi keuangan yang mewakili realitas perusahaan dan potensi-potensi kinerja akan berlanjut. (Linda Kania Dewi, 2015). Analisis keuangan dan potensi perusahaan, merupakan faktor yang paling utama untuk mendapatkan perhatian investor adalah aktivitas, likuiditas, solvabilitas dan profitabilitas (Munawir, 2004).

\section{Gambar 1.2}

\section{Rata-rata Return On Assets Industri}

Food and Beverage

Periode 2010-2015

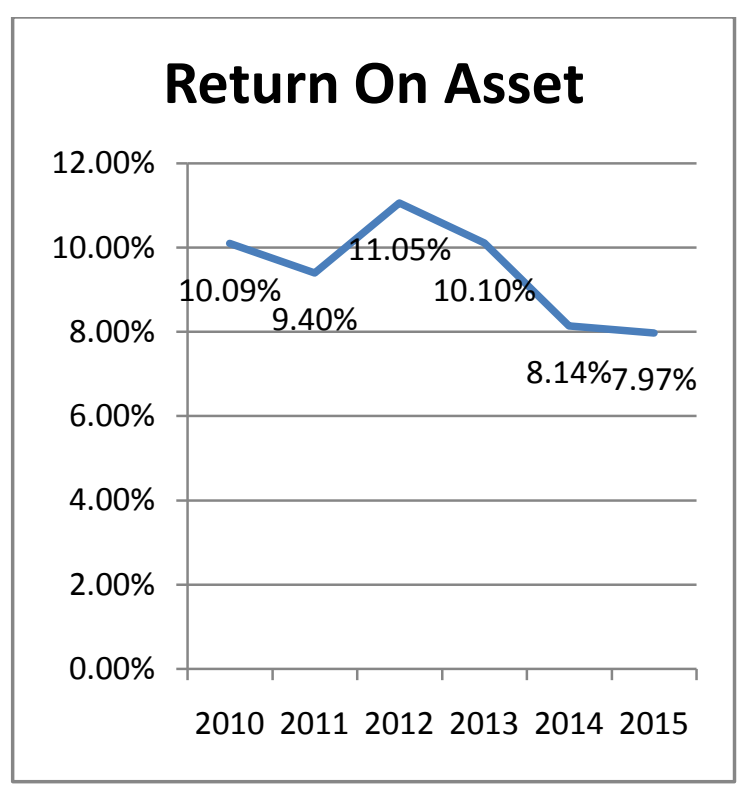

Sumber : Bursa Efek Indonesia diolah

Pada grafik diatas terlihat bagaimana perkembangan Return On Asset dari tahun 2010 sampai dengan tahun 2015 
pada 9 perusahaan Food and Beverage yang terdaftar di Bursa efek Indonesia. dalam kurun waktu 6 tahun Return On Asset mengalami Fluktuasi dengan kecenderungan menurun. Penurunan paling tinggi terjadi pada tahun 2015 dan kenaikan tertinggi terjadi di tahun 2012.

Return On Asset (ROA) merupakan indikator dalam rasio Pofitabilitas menunjukan seberapa besar presentase laba bersih yang diperoleh dari penggunaan aktiva. Rasio tersebut merupakan pengukuran efisiensi perusahaan dengan melihat besar kecilnya laba usaha dalam hubungannya dengan penggunaan aktiva. Menurut Lesatari dan Sugiharto (2007 : 196) dalam Rinati (2008:6) semakin tinggi rasio ini maka semakin baik produktivitas assets dalam memperoleh keuntungan bersih.

\section{Gambar 1.3}

Rata-rata Debt to Total Asset Industri Food and Beverage

Periode 2010-2015

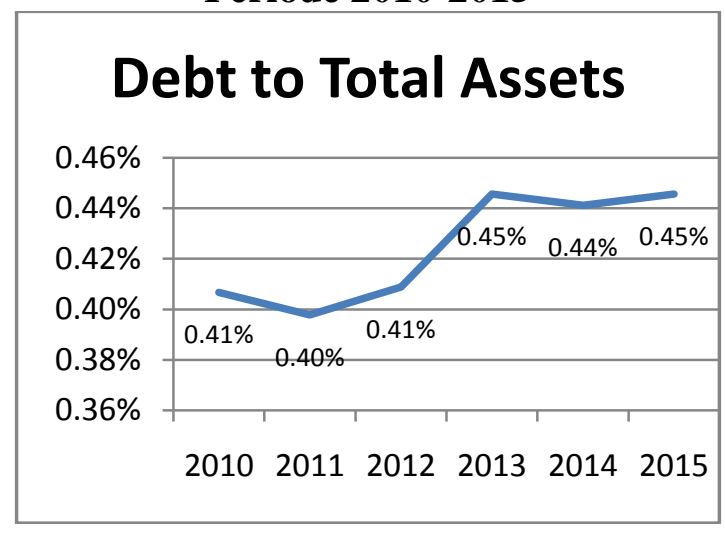

Sumber : Bursa Efek Indonesia diolah Dari grafik diatas bagaiaman Debt to Total Asset mengalami fluktuasi dari tahun 2010 sampai dengan tahun 2015 pada 9 perusahaan Food and Beverage yang terdaftar di Bursa efek Indonesia. terlihat bahwa kenaikan tertinggi terjadi pada tahun 2013 dan 2015, sedangkan penurunan paling tinggi terjadi pada tahun 2011.

Debt to Tottal Asset (DAR) merupakan salah satu rasio Solvabilitas yang menunjukan seberapa besar jumlah aktiva perusahaan yang dibiayai oleh hutang. Semakin tinggi rasio ini berarti semakin besar jumlah modal pinjaman yang digunakan untuk investasi pada aktiva guna menghasilkan keuntungan bagi perusahaan. Tingginya penggunaan hutang ini memiliki resiko yang besar namun apabila perusahaan dapat mengelola hutangnya dengan baik, penggunaan hutang ini dinilai menguntungkan bagi pemegang saham.

\section{Gambar 1.4}

Rata-Rata Net Profit Margin Industri Food and Beverage Periode 2010-2015

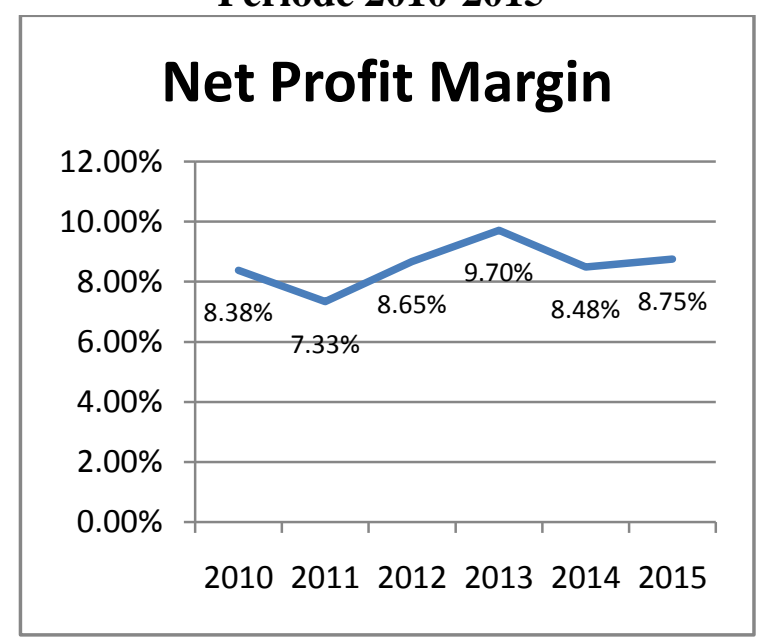

Sumber : Bursa Efek Indonesia diolah 
Grafik diatas menunjukan pergerakan Net Profit Margin selama 6 periode yaitu tahun 2010 sampai dengan tahun 2015 yang mengalami fluktuasi. Pada tahun 2010 ke 2011 Net Profit Margin mengalami penurunan yaitu 8,38 menjadi 7,33. Pada tahun 2012 mengalami kenaikan kembali sebesar 8,65. Dan kenaikan paling tinggi terjadi pada tahun 2013 yaitu sebesar 9,70. Pada tahun 2014 dan 2015 mengalami penurunan kembali yaitu sebesar 8,48 pada 2014 dan 8,75 pada 2015. Dengan kondisi tersebut dapat ditarik kesimpulan bahwa Net Profit Margin pada 9 perusahaan Food and Beverage mengalami Fluktuasi terlihat dari tahun 2010 sampai dengan 2015 yang mengalami perubahan baik penurunan maupun kenaikan.

Net Profit Margin (NPM) merupakan rasio profitabilitas menunjukan seberapa besar persentase laba bersih yang diperoleh dari setiap penjualan. Rasio tersebut merupakan pengukuran efisien perusahaan dengan melihat seberapa besar laba usaha dalam hubungannya dengan penjualan. Semakin besar rasio ini, maka dianggap semakin baik kemampuan perusahaan untuk mendapatkan laba yang tinggi (Menurut Bastian dan Suhardjono (2006: 299). Hal ini tentunya akan meningkatkan laba yang tersedia bagi pemegang saham.
Berdasarkan uraian diatas, maka permasalahan dalam penelitian ini :

1. Apakah terdapat pengaruh RETURN ON ASSET (ROA) terhadap harga saham pada perusahaan food and baverage yang terdaftar di Bursa Efek Indonesia?

2. Apakah terdapat pengaruh $D E B T$ TO TOTAL ASSET (DAR) terhadap harga saham pada perusahaan food and beverage yang terdaftar di Bursa Efek Indonesia?

3. Apakah terdapat pengaruh NET PROFIT MARGIN (NPM) terhadap harga saham pada perusahaan food and beverage yang terdaftar di Bursa Efek Indonesia?

4. Apakah terdapat pengaruh Return On Asset (ROA), Debt to total Asset (DAR), dan Net Profit Margin (NPM) terhadap harga saham pada perusahaan Food and Baverage yang terdaftar di Bursa Efek Indonesia?

\section{KAJIAN PUSTAKA DAN PENGEMBANGAN HIPOTESIS}

\section{Manajemen Keuangan}

Manajemen keuangan dapat didefinisikan dari tugas dan tanggung jawab manajer keuangan. Meskipun tugas dan tanggung jawabnya berlainan di setiap 
perusahaan, tugas pokok manajemen keuangan antara lain meliputi : keputusan tentang investasi, pembiayaan kegiatan usaha dan pembagian dividen suatu perusahaan (Weston dan Copeland, 1992: 2)

Menurut Sutrisno (2009: 3) "Manajemen Keuangan adalah sebagai semua aktivitas perusahaan yang berhubungan dengan usaha-usaha mendapatkan dana perusahaan dengan biaya yang murah serta usaha untuk menggunakan dan mengalokasikan dana tersebut secara efisien".

Dari definisi diatas dapat di ambil kesimpulan bahwa Manajemen Keuangan adalah salah satu fungsi manaejemen terhadap segala aktivitas perusahaan yang berhubungan dengan kegiatan memperoleh sumber dana, menggunakan dana, dan manajemen aktiva untuk menciptakan kemakmuran bagi pemegang saham melalui maksimalisasi nilai perusahaan.

\section{Laporan Keuangan}

Laporan keuangan merupakan ringkasan dari proses pencatatan, yang merupakan ringkasan dari transaksi keuangan yang terjadi selama tahun buku yang bersangkutan. Laporan keuangan ini dibuat oleh pihak manajemen dengan tujuan untuk mempertanggungjawabkan tugas yang dibebankan kepadanya oleh pemilik perusahaan (Baridwan, 1997).
Menurut Duwi Priyatno (2009) laporan keuangan merupakan laporan yang menginformasikan tentang posisi keuangan perusahaan yang tersusun secara rinci dan lengkap yang meliputi Neraca, Laba Rugi, Neraca Saldo dan sebagainya. Laporan ini digunakan bagi pihak internal dan eksternal untuk dapat menilai suatu perusahaan, seperti menilai keberhasilan perusahaan dalam usahanya atau menilai perkembangan perusahaan tersebut.

Berdasarkan pengertian diatas dapat disimpulkan bahwa laporan keuangan merupakan informasi yang dapat menggambarkan kondisi perusahaan pada periode tertetu yang dapat berguna bagi pihak internal dan eksteral perusahaan.

\section{Harga Saham}

Menurut Fred dan Copeland (1999: 166) saham merupakan tanda penyertaan atau kepemilikan seseorang atau badan dalam suatu perusahaan, selembar saham adalah selembar kertas yang menerangkan bahwa pemilik kertas tersebut adalah pemiliknya (berapapun porsinya atau jumlahnya) dari suatu perusahaan yang menerbitkan kertas (saham) tersebut. Selembar saham mempunyai nilai atau harga. Harga saham dapat dibedakan menjadi 3 (tiga), yaitu:

\section{A. Harga Nominal}


Harga yang tercantum dalam sertifikat saham yang ditetapkan oleh emiten untuk menilai setiap lembar saham yang dikeluarkan. Besarnya harga nominal memberikan arti penting saham karena deviden minimal biasanya ditetapkan berdasarkan nilai nominal.

\section{B. Harga Perdana}

Harga ini merupakan harga pada waktu harga saham tersebut dicatat di bursa efek. Harga saham pada pasar perdana biasanya ditetapkan oleh penjamin emisi (underwriter) dan emiten. Dengan demikian akan diketahui berapa harga saham emiten itu akan dijual kepada masyarakat biasanya untuk menentukan harga perdana.

\section{Harga pasar}

Kalau harga perdana merupakan harga jual dari perjanjian emisi kepada investor, maka harga pasar adalah harga jual dari investor yang satu dengan investor yang lain. Harga ini terjadi setelah saham tersebut dicatatkan di bursa. Transaksi di sini tidak lagi melibatkan emiten dari penjamin emisi harga ini yang disebut sebagai harga di pasar sekunder dan harga inilah yang benar-benar mewakili harga perusahaan penerbitnya, karena pada transaksi di pasar sekunder, kecil sekali terjadi negosiasi harga investor dengan perusahaan penerbit. Harga yang setiap hari diumumkan di surat kabar atau media lain adalah harga pasar

\section{Return On Asset}

Menurut Mardiyanto (2009) ROA adalah rasio yang digunakan untuk mengukur kemampuan perusahaan dalam menghasilkan laba yang berasal dari aktivitas investasi. Rasio ini digunakan untuk mengukur kemampuan manajemen dalam memperoleh keuntungan (laba) secara keseluruhan.

Untuk menghitung Return On Asset (ROA) dapat dirumuskan sebagai berikut:

\section{LabaBersih}

\section{ROA $=\longrightarrow \times 100 \%$ \\ TotalAktiva}

\section{Debt to Asset Ratio}

Menurut Munawir (2010: 105), Debt to Assets Ratio adalah rasio antara total hutang dengan aktiva. Rasio ini digunakan untuk mengukur seberapa besar jumlah aktiva perusahaan dibiayai dengan total hutang. Semakin tinggi rasio ini berarti semakin besar jumlah modal pinjaman yang digunakan untuk investasi pada aktiva guna menghasilkan keuntungan bagi perusahaan.

Menurut Joel dan Jae, debt ratio merupakan ukuran yang dipakai dalammenganalisis laporan keuangan 
untukmemperlihatkan

besarnya

jaminanyang tersedia untuk kreditor.

Semakinrendah debt ratio maka

akanmeningkatkan laba sehingga

semakinbesar jaminan kreditor

untukpengembalian atas pinjaman yangdiberikan oleh pihak perusahaan (Fahmi, 2012: 73).

Untuk menghitung Debt to total Asset Ratio dapat dihitung menggunakan rumus:

\section{Total Hutang}

\section{$\mathrm{DAR}=\mathbf{X 1 0 0 \%}$}

\section{Total Asset}

\section{Net Profit Margin}

Menurut Alexandri (2008: 200) Net Profit Margin (NPM) adalah rasio yang digunakan untuk menunjukkan kemampuan perusahaan dalam menghasilkan keuntungan bersih setelah dipotong pajak.

Sedangkan Kasmir (2008, hal. 200) berpendapat: "Margin laba bersih merupakan ukuran keuntungan dengan membandingakn antara laba setelah bunga dan pajak dibandingkan dengan penjualan. Rasio ini menunjukkan pendapatan bersih perusahaan atas penjualan".

Rasio ini dapat dirumuskan sebagai berikut:

\section{Laba bersih setelah pajak}

$\mathbf{N P M}=$

\section{Penjualan}

\section{PENGEMBANGAN HIPOTESIS}

Berdasarkan bab sebelumnya dan kerangka pemikiran, maka hipotesis dalam penelitian ini adalah:

1. Ada pengaruh yang signifikan Return On Asset terhadap Harga Saham pada Perusahaan Food and Baverage yang terdaftar di BEI.

2. Ada pengaruh yang signifikan Debt to total Asset Ratio terhadap Harga Saham pada Perusahaan Food and Baverage yang terdaftar di BEI.

3. Ada pengaruh yang signifikan Net Profit Margin terhadap Harga Saham pada Perusahaan Food and Baverage yang terdaftar di BEI.

4. Ada pengaruh yang signifikan Return On Asset, Debt to total Asset Ratio, dan Net Profit Margin terhadap Harga Saham pada Perusahaan Food and Baverage yang terdaftar di BEI.

\section{METODOLOGI PENELITIAN}

Penelitian ini menggunakan data sekunder. Data-data dalam penelitian ini merupakan data-data yang diperoleh melalui web IDX dari Bursa Efek Indonesia (BEI) berupa laporan keuangan serta harga saham 
pertahun emiten/perusahaan selama tahun pengamatan 2010-2015.

Populasi dalam penelitian ini yaitu perusahaan Food and Beverage yang terdaftar di Bursa Efek Indonesia (BEI). Pemilihan sampel dalam penelitian ini menggunakan metode Purpose Sampling yaitu tekhnik penentuan sampel dengan menggunakan pertimbangan dan kriteria tertentu dalam melakukan pemilihan sampel.

Metode analisis yang digunakan adalah analisis deskriptif dan regresi linier ganda. Hasil analisis regresi linier ganda yang utama adalah nilai koefisien korelasi $\mathrm{R}$, nilai koefisien determinasi Adjusted $\mathrm{R}$ Square, dan model persamaan regresi linier ganda:

$\mathrm{Y}=\mathrm{a}+\mathrm{b} 1 \mathrm{X} 1+\mathrm{b} 2 \mathrm{X} 2+\mathrm{b} 3 \mathrm{X} 3+\mathrm{b} 4 \mathrm{X} 4+\mathrm{e}$

\section{Keterangan:}

$\mathrm{X} 1$ = Return On Asset (ROA)

$\mathrm{X} 2=$ Debt to total Asset Ratio (DAR)

$\mathrm{X} 3=$ Net Profit Margin (NPM)

X4 = ROA, DAR, NPM

$\mathrm{Y}=$ Harga Saham $\mathrm{a}=$ Konstanta

$\mathrm{e}=$ Error

b1 = Koefisien Regresi Return On Asset (ROA)

b2 = Koefisien Regresi Debt to total Asset Ratio (DAR)

b3 = Koefisien Regresi Net Profit Margin (NPM)

b4 = Koefisien regresi ROA, DAR, NPM

\section{HASIL PENELITIAN DAN}

PEMBAHASAN

Berdasarkan hasil pengujian normalitas dan asumsi klasik, maka data memenuhi unsur-unsur tersebut. Dimana data berdistribusi normal dan terbebas dari persoalan Multikolonieritas, Heteroskedastisitas dan Autokolerasi. Sehingga analisis dapat dilanjutkan kejenjang berikutnya, yaitu analisis regresi dan pengujian Goodness Of Fit.

Analisis regresi dilakukan dengan menempatkan ROA,DAR dan NPM sebagai variabel independen dan Harga Saham sebagai variabel dependen. Hasil analisis regresi dapat dilihat pada Tabel 1 berikut ini. 
Tabel 1. Hasil Pengujian Regresi

Coefficients $^{\mathrm{a}}$

\begin{tabular}{|c|c|c|c|c|c|c|c|c|}
\hline \multirow{2}{*}{\multicolumn{2}{|c|}{ Model }} & \multicolumn{2}{|c|}{$\begin{array}{l}\text { Unstandardized } \\
\text { Coefficients }\end{array}$} & \multirow{2}{*}{\begin{tabular}{|c|}
$\begin{array}{c}\text { Standardi } \\
\text { zed } \\
\text { Coefficie } \\
\text { nts }\end{array}$ \\
\\
Beta \\
\end{tabular}} & \multirow[b]{2}{*}{$\mathrm{T}$} & \multirow[b]{2}{*}{ Sig. } & \multicolumn{2}{|c|}{$\begin{array}{c}\text { Collinearity } \\
\text { Statistics }\end{array}$} \\
\hline & & B & Std. Error & & & & $\begin{array}{c}\text { Toleranc } \\
\mathrm{e}\end{array}$ & VIF \\
\hline \multirow[t]{4}{*}{1} & (Constant) & .291 & .906 & & .322 & .749 & & \\
\hline & Log_ROA_1 & 1.543 & .905 & .473 & 1.705 & .094 & .207 & 4.840 \\
\hline & Log_DAR & -.304 & .926 & -.057 & -.328 & .744 & .520 & 1.925 \\
\hline & Log_NPM_1 & -2.184 & .660 & -.772 & -3.309 & .002 & .291 & 3.432 \\
\hline
\end{tabular}

a.DependentVariable:Log_HARGASAHAM

Sumber : Hasil output SPSS

Berdasarkan tabel diatas persamaan model regresi linier berganda dalam penelitian ini dapat dinyatakan sebagi berikut:

\section{Harga Saham $=0,291+1,543$ ROA -$$
\text { 0,304 DAR - 2,184 }
$$$$
\text { NPM }
$$

Koefisien regresi ROA sebesar b1 $=1.543$ memiliki nilai probabilitas $\mathrm{t}$ hitung sebesar sig $\mathrm{t}=0.094$. karena b1 \# 0 dan probabilitas $\mathrm{t}$ hitung lebih besar daripada taraf uji penelitian (0.094 > 0.05) maka Ho diterima dan Ha ditolak, yang berarti pengaruh parsial ROA terhadap Harga Saham tidak signifikan.

Koefisien regresi DAR sebesar b2 $=-0.304$ memiliki nilai probabilitas $\mathrm{t}$ hitung sebesar Sig $\mathrm{t}=0.744$. karena b2 \# 0 dan probabilitas $\mathrm{t}$ hitung lebih besar daripada taraf uji penelitian (0.744>0.05), maka Ho diterima dan Ha ditolak, yang berarti pengaruh parsial DAR terhadap Harga Saham tidak signifikan.

Koefisien regresi NPM sebesar b1 $=-2.184 \quad$ memiliki nilai probabilitas $\mathrm{t}$ hitung sebesar sig $\mathrm{t}=0.002$. karena b1\#0 dan probabilitas $\mathrm{t}$ hitung lebih kecil daripada taraf uji penelitian $(0.002$ $<$ 0.05) maka Ho ditolak dan Ha diterima, yang berarti pengaruh parsial NPM terhadap Harga Saham signifikan. Signifikansi hasil pengujian membuktikan adanya pengaruh parsial NPM terhadap Harga Saham yang bernilai negatif. 
Koefisien determinasi digunakan untuk mengukur seberapa jauh kemampuan model dalam menerangkan variasi variabel independen. Hasil pengujian koefisien determinasi dapat dilihat pada Tabel 2 berikut ini.

Tabel 2. Koefisien Determinasi

Model Summary ${ }^{b}$

\begin{tabular}{|l|r|r|r|r|}
\hline Model & $\mathrm{R}$ & \multicolumn{1}{|c|}{ R Square } & Adjusted R Square & \multicolumn{2}{c|}{$\begin{array}{c}\text { Std. Error of the } \\
\text { Estimate }\end{array}$} \\
\hline 1 & $.455^{\mathrm{a}}$ & .207 & .159 & .81528 \\
\hline
\end{tabular}

a. Predictors: (Constant), Log_NPM_1, Log_DAR, Log_ROA_1

b. Dependent Variable: Log_HARGASAHAM

Sumber : Hasil output SPSS

Tabel 3. Uji F

ANOVA $^{b}$

\begin{tabular}{|rl|r|r|r|r|r|}
\hline Model & & Sum of Squares & Df & Mean Square & F & Sig. \\
\hline 1 & Regression & 8.665 & 3 & 2.888 & 4.345 & .008 \\
& Residual & 33.234 & 50 & .665 & & \\
& Total & 41.899 & 53 & & & \\
\hline
\end{tabular}

a. Predictors: (Constant), Log_NPM_1, Log_DAR, Log_ROA_1

b.DependentVariable:Log_HARGASAHAM

Sumber : Hasil output SPSS

Koefisien determinasi ganda $\mathrm{R} 2=0.455$ memiliki nilai probabiltas $\mathrm{F}$ hitung sebesar Sig $F=0.008$. karena $p \quad \# \quad 0$ dan probabilitas $\mathrm{F}$ hitung lebih kecil daripada taraf uji penelitian (Sig F <Alpha yaitu $0.008<0.05$ ), maka Ho ditolak dan $\mathrm{Ha}$ diterima yang berarti pengaruh simultan ROA,DAR dan NPM terhadap Harga Saham adalah signifikan. Signifikansi hasil pengujian membuktikan adanya pengaruh
ROA, DAR dan NPM secara bersamasama terhadap Harga Saham.

\section{PEMBAHASAN}

1. Pengaruh Return On Asset Terhadap harga Saham.

Pengujian secara parsial ROA tidak berpengaruh terhadap Harga Saham, hal ini dibuktikan dengan Nilai t-hitung $(1,705)$ dan nilai signifikansinya $(0,094)$ lebih besar dari 0,05 maka Ho 
ditolak, yang berarti Return On Asset(ROA) tidak berpengaruh terhadap perubahan harga saham. Return On Asset(ROA) ratio yang digunakan untuk mengukur kemampuan perusahaan dalam menghasilkan laba yang berasal dari aktivitas investasi. Penelitian ini berbeda dengan penelitian Reina Damayanti dan Reva Maria Valianti (2016) yang mengatakan bahwa ada pengaruh signifikan antara Return On Asset terhadap Harga Saham pada perusahaan Indeks LQ-45 yang terdaftar di Bursa Efek Indonesia.

2. Pengaruh Debt to Total Asset Terhadap Harga Saham.

Pengujian secara parsial Debt to Total Asset (DAR) berpengaruh negatif dan tidak signifikan terhadap Harga Saham, hal ini dibuktikan dengan Nilai t-hitung $(-0,328)$ dan nilai signifikansinya $(0,744)$ lebih besar dari 0,05 maka Ha ditolak, yang berarti Debt to Total Asset(DAR) tidak berpengaruh secara signifikan terhadap harga saham. Debt to Assets Ratio adalah rasio antara total hutang dengan aktiva. Rasio ini digunakan untuk mengukur seberapa besar jumlah aktiva perusahaan dibiayai dengan total hutang. Semakin tinggi rasio ini berarti semakin besar jumlah modal pinjaman yang digunakan untuk investasi pada aktiva guna menghasilkan keuntungan bagi perusahaan. Hasil penelitian ini mendukung penelitian Reina Damayanti dan Reva Maria Valianti (2016) yang menyatakan Debt to Total Assetberpengaruh signifikan terhadap Harga Saham.

3. Pengaruh Net Profit Margin Terhadap Harga Saham Pengujian secara parsial Net Profit Margin (NPM) berpengaruh negatif dan signifikan terhadap Harga Saham, hal ini dibuktikan dengan Nilai t-hitung ($3,309)$ dan nilai signifikansinya $(0,002)$ lebih kecil dari 0,05 maka Ha diterima, yang berarti Net Profit Margin (NPM) berpengaruh secara signifikan terhadap harga saham. Net Profit Margin adalah perbandingan antara laba bersih dengan penjualan. Semakin besar NPM, maka kinerja perusahaan akan semakin produktif, sehingga akan meningkatkan kepercayaan investor untuk menanamkan modalnya pada perusahaan tersebut. Rasio ini menunjukkan berapa besar persentase laba bersih yang diperoleh dari setiap penjualan. Hasil penelitian ini mendukung penelitian Edduar Hendri (2015) yang menyatakan Net Profit Margin berpengaruh signifikan terhadap harga saham pada perusahaan perbankan yang terdaftar di Bursa Efek Indonesia. 


\section{SIMPULAN DAN KETERBATASAN}

Hasil pengujian hipotesis dengan menggunakan analisis regresi linier berganda. Dimana hasil penelitian ini menunjukan bahwa:

1. Hasil pengujian Return On Asset, Debt to Total Asset dan Net Profit Margin simultan ( uji F) menunjukan pengaruh secara signifikan dan simultan terhadap harga saham pada perusahaan Food and Beverage yang terdaftar di Bursa Efek Indonesia selama periode 2010-2015. Koefisien determinasi ganda $\mathrm{R} 2=$ 0.455 memiliki nilai probabiltas $\mathrm{F}$ hitung sebesar Sig F = 0.008. karena $\mathrm{p} \#$ 0 dan probabilitas $\mathrm{F}$ hitung lebih kecil daripada taraf uji penelitian (Sig $\mathrm{F}$ $<$ Alpha yaitu $0.008<0.05$ ), maka Ho ditolak dan $\mathrm{Ha}$ diterima yang berarti pengaruh simultan ROA,DAR dan NPM terhadap Harga Saham adalah signifikan.

2. Return On Asset (ROA) secara parsial memiliki pengaruh positif dan tidak signifikan terhadap Harga Saham pada perusahaan Food and Beverage. Koefisien regresi ROA sebesar b1 = 1.543 memiliki nilai probabilitas $\mathrm{t}$ hitung sebesar sig $\mathrm{t}=0.094$. karena $\mathrm{b} 1$ \# 0 dan probabilitas t hitung lebih besar daripada taraf uji penelitian (0.094 > 0.05) maka Ho diterima dan Ha ditolak , yang berarti pengaruh parsial ROA terhadap Harga Saham tidak signifikan.
Hal ini menunjukan bahwa ROA yang tinggi tidak dapat meningkatkan Harga Saham secara signifikan sehingga ROA tidak dapat dijadikan ukuran tingkat pengembalian atas investasi yang dilakukan oleh investor.

3. Debt to Total Asset (DAR) secara parsial memiliki pengaruh negatif dan tidak signifikan terhadap harga saham pada perusahaan Food and Beverage. Koefisien regresi DAR sebesar b2 = 0.304 memiliki nilai probabilitas $\mathrm{t}$ hitung sebesar Sig $\mathrm{t}=0.744$. karena $\mathrm{b} 2$ \# 0 dan probabilitas $t$ hitung lebih besar daripada taraf uji penelitian (0.744>0.05), maka Ho diterima dan Ha ditolak, yang berarti pengaruh parsial DAR terhadap Harga Saham tidak signifikan.Hal ini menunjukan bahwa besar atau kecilnya nilai DAR tidak berpengaruh terhadap harga saham.

4. Net Profit Margin (NPM) secara parsial memiliki pengaruh negatif dan signifikan terhadap Harga Saham pada perusahaan Food and Beverage. Koefisien regresi NPM sebesar b1 = 2.184 memiliki nilai probabilitas $\mathrm{t}$ hitung sebesar sig $\mathrm{t}=0.002$. karena $\mathrm{b} 1$ \# 0 dan probabilitas $\mathrm{t}$ hitung lebih kecil daripada taraf uji penelitian $(0.002<$ 0.05) maka Ho ditolak dan Ha diterima, yang berarti pengaruh parsial NPM terhadap Harga Saham signifikan. Signifikansi hasil pengujian 
membuktikan adanya pengaruh parsial NPM terhadap Harga Saham yang bernilai negatif. Hal ini menunjukan tingkat NPM yang tinggi menunjukan perusahaan mempunyai kemampuan menghasilkan laba bersih yang tinggi dalam pendapatan operasionalnya. Hasil dari perhitungan ini mencerminkan keuntungan bersih per rupiah penjualan. Jadi perusahaan yang memiliki NPM yang tinggi menunjukan kinerja perusahaan yang semakin produktif dalam menghasilkan laba. Ini dikarenakan laba sebagian besar dihasilkan dari penjualan yang merupakan operasi utama perusahaan. Dengan semakin produktifnya perusahaan dalam menghasilkan penjualan ini maka penghasilan yang diperoleh pemegang saham pada setiap lembarnya semakin besar.

\section{Keterbatasan Penelitian}

Penelitian menyadari sepenuhnya bahwa penelitian yang telah dilakukan ini walaupun telah diupayakan semaksimal mungkin tetap masih mempunyai keterbatasan-keterbatasan yang sulit untuk dihindari ,Berikut ini keterbatasan penelitian yang ada dalam penelitian ini :

1. Penelitian ini memiliki sampel yang sedikit kibat adanya persyaratan sampek harus dipenuhi untuk mendapatkan hasil analisis yang lebih baik.

2. Penelitian ini hanya terbatas pada Return On Asset (ROA), Debt to Total Asset (DAR)dan Net Profit Margin(NPM), tidak menggunakan aspek lain sehingga hasil penelitian tidak dapat menggambarkan situasi secara keseluruhan.

3. Periode penelitian yang relatif singkat selama enam tahun dari tahun 2010 sampai dengan tahun 2015. Dengan pendeknya periode penelitian dan jumlah data yang terbatas, yaitu 9 perusahaan yang menjadi sampel penelitian sehingga jumlah data yang terkumpul sebanyak 54, sehingga hasilnya kurang optimal.

4. Jenis perusahaan yang digunakan sebagai sampel dalam penelitian ini hanya perusahaan Food and Beverage, sehingga belum dapat mencerminkan hasil dari perusahaan yang terdaftar di Bursa Efek Indonesia.

\section{DAFTAR PUSTAKA}

\section{BUKU}

Alexandri, Moh. Benny. 2008. Manajemen Keuangan Bisnis. Cetakan Kesatu. Bandung: Alfabeta.

Alwi, Iskandar Z, 2008. Pasar Modal Teori dan Aplikasi, Yayasan Pancur Siwah, Jakarta.

Anoraga, Pandji, dan Pakarti Piji. 2001. Pengantar Pasar Modal. Edisi Revisi. PT. Asdi Mahasatya. Jakarta. 
Baridwan, Zaki.1997. Intermediate Accaunting. Yayasan : Balai Penerbit FE Yogyakarta.

Bastian, Indra dan Suhardjono. 2006. Akuntansi Perbankan. Edisi 1. Jakarta: Salemba Empat.

Fahmi, Irham. 2014. Manajemen Perusahaan pasar modal. Mitra Wicana : Jakarta.

Fred, Weston, J. dan Thomas E. Copeland. 1999. Manajemen Keuangan. Edisi 8. Jakarta: Bina Rupa Aksara.

Ghozali, Imam 2005. Aplikasi Analisis Multivariate dengan Program SPSS. Badan Universitas Diponegoro: Semarang.

Multivariate Dengan Program SPSS. Semarang : BP Universitas Dipenogoro.

Gibson, Charles H. 2001. Financial Reporting Analysis. Edisi Delapan, South Western College Publishing.

Gitman, J. Lawrence, 2006. Principles of Managerial Finance. Edisi Sebelas. Boston: Pearson Addison Wesley.

Horne, James C. Van dan John M. Wachowicz JR. 2005. Fundamental Of Financial Management. Prinsipprinsip Manajemen Keuangan. Buku satu. edisi keduabelas. alih bahasa oleh Dewi Fitriasari dan Dony Arnos Kwary. Jakarta: PT Salemba Empat.

Husnan, Suad. 2002. Dasar-dasar Teori Portofolio dan Analisis Sekuritas. Edisi Ketiga. Yogyakarta : AMP YKPN.
Ikatan Akuntansi Indonesia, 2012. Standar Akuntansi Keuangan. PSAK. Cetakan Keempat. Jakarta : Salemba Empat.

James C. Van Horne., \& John M. Wachowicz jr. (2012). PrinsipPrinsip Manajemen Keuangan (Edisi 13). Jakarta: Salemba Empat.

Kasmir. 2008. Bank dan Lembaga Keuangan Lainnya. Edisi Revisi 2008. Jakarta: PT. Raja Grafindo Persada.

2014. Analisis Laporan Keuangan. PT. Rajagrafindo Perkasa : Jakarta.

Lestari, Maharani Ika dan Toto Sugiharto. 2007. Kinerja Bank Devisa Dan Bank Non Devisa dan Faktor-Faktor Yang Mempengaruhinya. Proceeding PESAT (Psikologi, Ekonomi, Sastra, Arsitek \& Sipil). 21-22 Agustus, Vol.2. Fakultas Ekonomi, Universitas Gunadarma.

Mardiyanto, Handoyo. 2009. Intisari Manajemen Keuangan. Jakarta: PT Grasindo.

Mulyanto, Heru dan Wulandari, Anna.2010. Penelitian Metode dan Analisis. Semarang: CV. Agung.

Munawir. 2004. Analisa Laporan Keuangan. Edisi empat. Yogyakarta: Liberty.

Priyatno, Duwi. 2009. 3 Jam Selesaikan Laporan Keuangan MYOB \& Peachtree. Cetakan Pertama. Yogyakarta : Best Publisher.

S. Munawir. (2010). Analisa Laporan Keuangan. Edisi Keempat. Yogyakarta: Liberty. 
Suad Husnan dan Enny Pudjiastuti. 2004. Manajemen Keuangan Edisi Kelima. Yogyakarta: UPP AMP YKPN.

Sugiyono. 2004. Statistika untuk Penelitian. Bandung Alfabeta.

Sunariyah. (2004). Pengantar Pengetahuan Pasar Modal. Edisi Keempat. Yogyakarta: AMP YKPN.

Sutrisno. 2009. Manajemen Keuangan teori, Konsep dan aplikasi. Edisi Pertama. Cetakan ketujuh. Ekonisia Kampus Fakultas Ekonomi, Yogyakarta.

Syamsuddin, Lukman. 2009. Manajemen Keuangan Perusahaan Konsep Aplikasi dalam: Perencanaan, Pengawasan dan Pengambilan Keputusan. Edisi Baru. Jakarta: Raja Grafindo Persada.

Tandelin, Eduardus 2010:341, portofolio dan investasi teori dan aplikasi. Edisi Pertama. Yogyakarta: Kanisus

Weston J. Pred dan Thomas E. Copeland, Manajemen Keuangan, Penerbit Binarupa Aksara, Cetakan Pertama, 1992.

Widoatmodjo, Sawidji. (2005). Cara Sehat Investasi di Pasar Modal. Jakarta: PT. Jurnalindo Aksara Grafika.

Wild, John J., Subramayam, K. R., dan Halsey, Robert F. 2005. Financial Statement Analysis. Edisi 8. Buku Satu. Jakarta: Salemba Empat.

Indonesia." Jurnal The Winners, Vol. 14, No. 1, Halaman 29-41.

Valintino,Reynard dan Sularto, Lana (2013). "Pengaruh Return On Asset, Current Ratio, Return On equity, Debt to Equity Ratio dan Earning

\section{JURNAL ILMIAH}

Damayanti,Reina dan Maria Valianti, Reva (2016). "Pengaruh Debt to Total Asset Ratio, Debt to Equity Ratio, Return On Asset dan Net Profit Margin Terhadap Harga Saham Pada Perusahaan Indeks LQ-45 Di Bursa Efek Indonesia." Jurnal Media Wahana ekonomika, Vol.13, No.1, Halaman 16-36.

Febriyanto,Citra, Feri dan Nurwiyanta (2014). "Pengaruh Return On Equity ,Return On Asset dan Net Profit Margin Terhadap Harga Saham Pada Perusahaan Real Estate and Property Di Bursa Efek Indonesia Periode 2008-2011." Jurnal Bisnis dan Ekonomi, Vol.5, No.1, Halaman 1930.

Hendri, Edduar (2015). "Pengaruh Debt to Total Asset Ratio, Long Term Debt to Equity Ratio Dan Net Profit Margin Terhadap Harga Saham Pada Perusahaan Perbankan Yang Terdaftar Di Bursa Efek Indonesia." Jurnal Media Wahana Ekonomika, Vol. 12, No. 2, Halaman 1-19.

Khusaini, dkk (2014). "Pengaruh Debt to Equity Ratio, Dividen Per Share dan Return On Asset Terhadap Harga Saham Pada Perusahaan Telekomunikasi Di BEI.” Jurnal Ilmu dan Riset Manajemen, Vol.3, No.9, Halaman 1-15.

Ramdhani,Rani (2013). "Pengaruh Return On Asset Dan Debt to Equity Ratio Terhadap Harga Saham Pada Institusi Finansial Di Bursa Efek Per Share Terhadap Harga Saham Perusahaan Manufaktur Sektor Industri Barang Konsumsi Di BEI." Jurnal Proceeding PESAT, Vol. 5, Halaman 195-202. 
Watung,Widiawati,Rosdian dan Ilat,Ventje (2016). "Pengaruh Return On Asset,Net Profit Margin dan Earning Per Share Terhadap Harga Saham Pada Peusahaan Perbankan di Bursa Efek Indonesia Periode 20112015." Jurnal EMBA, Vol. 4, No.2, Halaman 518-529. 